\title{
Role of the lodothyronine Deiodinases in the Physiology and Pathophysiology of Thyroid Hormone Action
}

\author{
P. Reed Larsen Ann Marie Zavacki \\ Department of Medicine, Brigham and Women's Hospital and Harvard Medical School, Harvard Institutes of \\ Medicine, Boston, Mass., USA
}

\section{Key Words}

Deiodinase $\cdot$ Thyroxine $\cdot$ Triiodothyronine $\cdot$ Thiols •

Thyroid-stimulating hormone $\cdot$ Illness $\cdot$ Propylthiouracil $\cdot$ Selenium $\cdot$ Selenocysteine $\cdot$ lodine deficiency $\cdot$ Pregnancy $\cdot$ Hypothyroidism

\section{Abstract}

Thyroxine (T4) is a prohormone and must be activated to 3,5,3'-triiodothyronine (T3) by either type 1 (D1) or type 2 (D2) selenodeiodinase. A third deiodinase (D3) inactivates T3 or T4 by removal of an inner ring iodine. These reactions require both a deiodinase enzyme and a cofactor, probably a thiol, to reduce the oxidized selenolyl group in the active center of each deiodinase. Thus, deiodination rates depend on both the enzyme and cofactor. The source of most of the circulating T3 is D1-mediated, while D2 provides nuclear receptor-bound hormone. Using sensitive and specific assays, it has become apparent that both D2 and D3 are widespread throughout vertebrate tissues. The complex interactions between the activating D2 and the inactivating D3 in tissues expressing these two enzymes determine the intracellular T3 concentration. This provides enormous flexibility for both developmental and tissue regeneration processes, allowing exquisite control of intracellular T3 concentrations. The endogenous factors regulating the activity of these enzymes, such as the hedgehog proteins, FoxO3, or the wnt $/ \beta$ catenin pathway together with the actions of thyroid hormone transporters, direct adjustments of nuclear receptor-bound T3 which in turn can control the balance between cellular proliferation and differentiation. Their actions provide dynamic flexibility to what appears on the surface to be a very static hormonal system.

Copyright @ 2012 European Thyroid Association Published by S. Karger AG, Basel

\section{Introduction}

When dietary iodine is sufficient, the major product of the thyroid gland is thyroxine (T4) which is secreted at a rate of 10 -fold that of 3,5,3'-triiodothyronine (T3) in humans. Thus, a rate-limiting step in thyroid hormone action is the conversion of the prohormone T4 to T3. This is the major role of two enzymes - type 1 and 2 iodothyronine deiodinases (D1 and D2, respectively) (fig. 1). While the half-life of T4 in humans is about 1 week, that of T3 is much shorter, $<24 \mathrm{~h}$, and its inactivation in peripheral tissues by removal of an inner ring iodine from $\mathrm{T} 3$ is primarily due to the action of type 3 iodothyronine deiodinase (D3). As discussed below, there are two important systems for maintaining T3 homeostasis in vertebrates. These systems maintain the synthesis and secre-

\section{KARGER}

Fax +4161306 1234

E-Mail karger@karger.ch

www.karger.com
(C) 2012 European Thyroid Association

Published by S. Karger AG, Basel

2235-0640/12/0014-0232\$38.00/0

Accessible online at:

www.karger.com/etj
Dr. P. Reed Larsen

Department of Medicine, Brigham and Women's Hospital and Harvard Medical School Harvard Institutes of Medicine, Room 644

77 Avenue Louis Pasteur, Boston, MA 02115-5727 (USA)

E-Mail plarsen@partners.org 
Fig. 1. Pathways of iodothyronine deiodination by type 1, 2, and 3 iodothyronine deiodinases (D1, D2 and D3).

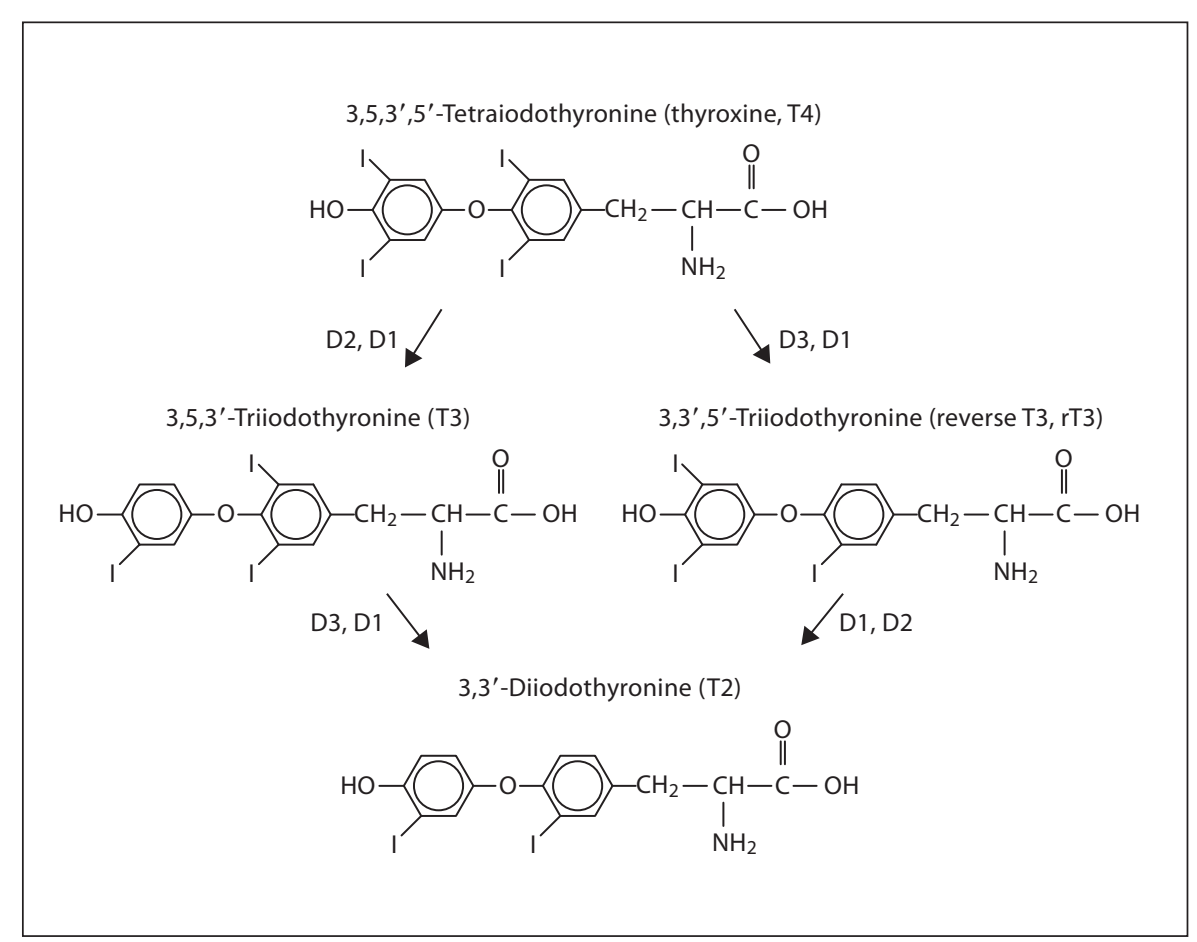

tion, and therefore the circulating concentration, of T4 at remarkably stable levels through the actions of thyrotropin-releasing hormone (TRH) and thyroid-stimulating hormone (TSH). However, since T4 is a prohormone, the systems controlling its secretion rate depend largely on the effects of the thyroid hormone receptor-bound T3 derived from it. Thus, the iodothyronine deiodinases which control the formation and degradation of T3 are critical to the maintenance of the euthyroid status.

The key to this process is the actions of the deiodinases which are subspecialized in different tissues. Most of the T3 in the circulation is derived from the actions of D1 in the liver, kidney, and thyroid [1]. However, in the hypothalamus and pituitary thyrotroph, D2 permits the feedback loop to recognize the concentrations of T4 due to the fact that T4 is rapidly converted by $\mathrm{D} 2$ to $\mathrm{T} 3$ in those cells [2-4]. In the anterior pituitary nuclei, approximately one-half of the T3 bound to nuclear receptors is derived from circulating $\mathrm{T} 3$ whereas the remaining half comes from intrapituitary T4 to T3 conversion [1]. Recent studies have illustrated that D2 is highly expressed in thyrotrophs and its activity is regulated by $\mathrm{T} 4$ posttranslationally, per se [5]. The D3 content of thyrotroph tumor cells is quite low, indicating that the ratelimiting step in the action of T3 on TSH is at the level of its formation from T4 and together with that from the plasma balanced by its efflux from the nucleus and cytosol.

The major steps in the actions of $\mathrm{T} 4$ are initiated by the entry of T4 into the cell which is now recognized to be controlled by expression of various thyroid hormone transporters [6-8]. It must then be converted to T3 either in D1- or D2-expressing cells, allowing a dual source of T3 (systemic and local) to the hypothalamic-pituitary (HPT) axis. After transport into the cell, cytosolic T3 then enters the nuclei of cells in the HPT by yet to be defined pathways, and then binds to high-affinity chromatin-bound proteins, predominantly the thyroid hormone receptor $\beta 2$ [9]. Due to the rapid generation of T3 from T4 within these cells by D2, the cytosolic T3 concentration is higher and remains in a static disequilibrium with the serum T3 $[1,10,11]$. We now appreciate that D2 is expressed in a large number of tissues (albeit at low levels in some), including skeletal muscle, osteoblasts, pituitary cells, astroglia, endothelial cells, retina, cochlea, placenta, endothelial cells, and, perhaps, others [12].

The expression of D3 is especially important during fetal development. D3 is preferentially expressed in neurons, but in Siberian hamsters D3 also appears to be found in specialized glial cells lining the lower portions of the third ventricle of the hypothalamus, termed tanycytes, where it is reciprocally regulated with $\mathrm{D} 2$ to main- 
tain local control of the T3 concentration [13-15]. These interlocking pathways allow remarkably stable concentrations of T3 while also facilitating specific chronotropic and tissue-specific changes in T3 concentrations during periods when developmental or regenerative programs call for a transient increase or decrease in specific cells. This change cannot be accomplished by alterations in TSH since this would change the supply of thyroid hormone to the entire organism. Thus, the control of intracellular T3 concentration is local and requires D2 and D3.

One striking example of the cooperation of these two pathways occurs in iodine deficiency which represents an enormous challenge for terrestrial vertebrates. Much of the iodine initially in the earth's crust has been eluted into the oceans by glaciation over many eons such that the soil content in many regions is inadequate to provide sufficient iodine in locally grown foodstuffs for the daily synthesis of sufficient T4. Under these circumstances, the HPT axis recognizes the deficiency of the prohormone T4 via its role as a substrate for D2 in the cells of the HPT axis. By an iterative process, D1-mediated T3 decreases but it is partly replenished by an increase in thyroidal T3 production by increased TSH secretion, as well as by increased efficiency of D2-mediated T3 formation. At the same time, the T3-dependent Dio3 gene transcription decreases, reducing neuronal D3 and prolonging the halflife of T3 [16]. This combination allows a decrease in the feedback suppression of TRH and TSH where the latter causes thyroid cell hyperplasia, and increases the sodium iodide symporter, thyroidal D1 and D2, thyroglobulin turnover, and the ratio of T3:T4 in thyroidal secretion. Thus, virtually all of these internal adjustments, including the downregulation of the T3-dependent D1 in the liver and kidney and increases in D2, permit conservation of whatever T4 can be secreted by the thyroid for the production of $\mathrm{T} 3$.

It is important to recall that the thyroid physiology of humans, especially those who are iodine-sufficient, differs considerably from that of rodents, the model animals for many of the experiments used to examine these adaptations. In humans, $80-90 \%$ of the T3 is formed by outer ring deiodination of T4. It is of interest in the context of this new journal that the first demonstration of T4 to T3 conversion in humans was provided by Dr. Rosalind PittRivers, a founding member of the European Thyroid Association [17]. In human thyroglobulin, the molar ratio of T4:T3 is about $15: 1$, with each $660,000 \mathrm{kDa}$ molecule of this thyroidal protein containing approximately 3-4 residues of T4 while only about 1 in 5 contains a T3 residue
[18]. While the expression of both D1 and D2 in the human thyroid cell increases T4 to T3 conversion such that the $\mathrm{T} 4: \mathrm{T} 3$ ratio is approximately 10:1 in thyroid secretion, this accounts for only a minor portion of circulating $\mathrm{T} 3$ in humans [19]. On the other hand, the thyroglobulin of the mouse and the rat have much lower T4:T3 ratios, about 3-4:1, and thus about half of the circulating T3 in these species derives directly from thyroid secretion [20]. This is especially important to note in the mouse in which a genetic inactivation of either or both D1 and D2 does not change serum T3 concentrations [21].

\section{General Properties of the lodothyronine Deiodinases}

There are important common features of the three deiodinases which should be noted (table 1). They are all integral membrane proteins, although they are expressed in different cellular locations. D1 is found in the plasma membrane and D2 in the endoplasmic reticulum but both have their active centers in the cytosol, thus allowing access to cytosolic thiol cofactors $[1,22]$. The precise location of $\mathrm{D} 3$ has been more difficult to discern, with the likely location being the plasma membrane but it is recycled through endosomes such that it may have actions on both extracellular and intracellular T3. This may be very important for the differential response of T4 activation (by D1 and D2) and T4 and T3 inactivation (by D3) to oxidative stress (see below) [23].

Another common feature of the deiodinases is that they belong to the small family of 25 selenoproteins in the human genome. They contain the rare amino acid selenocysteine (Sec) encoded by UGA in their active centers [24]. The much higher nucleophilicity of selenium (as opposed to the sulfur of cysteine) makes these enzymes 100fold more efficient in catalyzing the reductive deiodination of iodothyronines when compared to a corresponding cysteine-containing mutant enzyme [25]. However, there is a 'price' to pay for this in that the translational efficiency of the mRNA encoding a selenoprotein is $\sim 20$ fold or more lower than that of the same protein containing cysteine due to the necessity to override the STOP codon function of UGA in order to cotranslationally insert selenocysteine $[25,26]$. This process requires a specific stem loop structure in the $3^{\prime}$ untranslated region of the mRNA termed a 'SECIS element' (fig. 2) [26, 27]. In the following sections, some of the more important physiological systems which depend on the iodothyronine deiodinases are reviewed (table 2). 
Table 1. Characteristics of iodothyronine deiodinases

\begin{tabular}{|c|c|c|c|}
\hline Property & D1 & D2 & D3 \\
\hline Location & plasma membrane & endoplasmic reticulum & plasma membrane \\
\hline $\begin{array}{l}\text { Active center } \\
\text { Susceptibility to inhibitors }\end{array}$ & cytosol & cytosol & cell surface \\
\hline Propylthiouracil & very high & very low & very low \\
\hline Iopanoic acid & high & high & high \\
\hline Tissue expression & liver, kidney, thyroid & $\begin{array}{l}\text { CNS, pituitary, thyroid, bone, brown } \\
\text { adipose tissue, cochlea, skeletal muscle, } \\
\text { retina, brain (glial cells, tanycytes) }\end{array}$ & $\begin{array}{l}\text { CNS, placenta, skin, } \\
\text { regenerating tissues, } \\
\text { uterus, fetus, brain (neurons) }\end{array}$ \\
\hline $\begin{array}{l}\text { Effect of thyroid status } \\
\text { Hypothyroidism }\end{array}$ & $\begin{array}{l}\text { decrease (kidney, liver) } \\
\text { increase (thyroid) }\end{array}$ & increase & decrease \\
\hline Hyperthyroidism & increase & decrease (except in the thyroid) & increase \\
\hline $\begin{array}{l}\text { Physiological regulation } \\
\text { Induction }\end{array}$ & $\begin{array}{l}\text { T3, retinoic acid, cAMP } \\
\text { TSH (in thyroid) }\end{array}$ & $\begin{array}{l}\text { sympathetic nervous system } \\
\text { high-fat diet } \\
\text { bile acid } \\
\text { cAMP } \\
\text { FOXO3 } \\
\text { cellular differentiation }\end{array}$ & $\begin{array}{l}\text { tissue injury } \\
\text { TGF- } \beta \text { and other growth factors } \\
\text { hypoxia (HIF-1) } \\
\text { regeneration } \\
\text { sonic hedgehog } \\
\text { cellular proliferation }\end{array}$ \\
\hline Repression & $\begin{array}{l}\text { fasting, illness, IL-6, IL-1 } \beta \\
\text { interferon }\end{array}$ & $\begin{array}{l}\text { T4 (posttranslational) } \\
\text { T3 (transcriptional) } \\
\text { ubiquitination } \\
\text { sonic hedgehog }\end{array}$ & $\begin{array}{l}\text { growth hormone } \\
\text { glucocorticoids } \\
\text { cellular differentiation }\end{array}$ \\
\hline Physiological role & $\begin{array}{l}\text { a major source of plasma T3 } \\
\text { clearance of rT3 and T3S }\end{array}$ & $\begin{array}{l}\text { hypothalamic-pituitary feedback } \\
\text { thermogenesis in BAT } \\
\text { tissue regeneration and differentiation } \\
\text { provide plasma T3 }\end{array}$ & $\begin{array}{l}\text { inactivation of } \mathrm{T} 3 \text { and } \mathrm{T} 4 \\
\text { cellular proliferation } \\
\text { tissue repair }\end{array}$ \\
\hline
\end{tabular}

\section{Thyroid Hormone Activation by D1 and D2}

D1 is the likely source of most of the plasma T3 in humans and it was the first deiodinase to be cloned and studied intensively $[1,24]$. Inhibition of D1 activity in the liver and kidney is commonly found in fasting or in illness, and a reduction in its function either through decreases in cofactor or T4 uptake, or an impairment of D1 transcription due to reduced T3, contributes to the reduction in serum T3 in sick patients [28]. This is often referred to as the 'low T3 syndrome'. Curiously, despite the fact that high D1 activity is expressed in the liver, kidney and thyroid, most of the T3 bound to the nuclear receptor in these tissues is derived from plasma T3. This is quite different from the situation in the pituitary and the cerebral cortex where most of the receptor-bound T3 derives from D2-mediated T4 to T3 conversion [1, 28, 29]. An- other unique feature of $\mathrm{D} 1$ is that its activity is blocked by propylthiouracil (PTU) [30]. This is thought to occur through the competition of the thiol group of PTU with the endogenous thiols which are required for the reduction of the Se-I complex formed during D1-mediated iodothyronine deiodination [31]. D1 expression is, somewhat paradoxically, induced transcriptionally by $\mathrm{T} 3$ in liver and kidney and by thyroid receptor-stimulating immunoglobulins in thyroid, explaining why PTU is so effective in blocking T3 formation in patients with hyperthyroidism [32, 33]. Severe hyperthyroidism (thyroid storm) is a major indication for the use of high-dose PTU in adults due to its effects on D1-mediated T4 to T3 conversion in liver, kidney, and thyroid tissues.

The fact that D1 is a T3-dependent protein contributes to the adjustments that occur in the patterns of T4 to T3 conversion in hypothyroidism. Human D1 monodeiodin- 
Table 2. Physiological systems in which deiodinases play critical roles

\begin{tabular}{ll}
\hline System & Deiodinase \\
\hline Thyroid hormone activation & D1 and D2 \\
Regulation of HPT axis & D1, D2, D3 \\
Tissue development and differentiation & D1, D2, D3 \\
Tissue repair & D2 and D3 \\
Maternal/fetal interactions & D2 and D3 \\
Thermogenesis & D2 \\
\hline
\end{tabular}

ates T4 in the outer ring forming T3, but is equally active in the inner ring monodeiodination of $\mathrm{T} 4$ producing reverse T3 (rT3), an inactive iodothyronine [34]. This is in sharp contrast to D2 which is exclusively an outer ring deiodinase. In hypothyroidism or in iodine deficiency, when T4 production is reduced, $\mathrm{D} 1$ activity is reduced while that of $\mathrm{D} 2$ is increased due to the fact that the T4-induced ubiquitination and proteasomal degradation of D2 is reduced. Thus, the half-life of cellular D2 is prolonged by the reduction in T4 $[35,36]$. Since the efficiency of T4 to T3 conversion by $\mathrm{D} 2$ is double that of $\mathrm{D} 1$, the shifting of ratios in favor of D2 increases the efficiency of activation of whatever residual T4 can be formed. This facilitates T3 homeostasis in serum and in peripheral tissues [1].

Tissue-specific actions of D2 are especially important during development. One of the most impressive examples of this occurs in the development of the inner ear in which a sharp spike in the activity of D2 occurs at P6-8 in the mouse which is required for normal cochlear development (fig. 3) [37]. If D2 is genetically inactivated, the animals are deaf, illustrating the necessity of this deiodinase for development of normal hearing [38]. D2 is also required for the normal development and regeneration of skeletal muscle after injury [39]. In D2 knockout mice, development and regeneration after injury is markedly delayed. The increase in D2 in skeletal muscle requires an increase in FoxO3, which has been shown to specifically stimulate Dio2 gene transcription through a conserved FoxO3-binding sequence [39].

The functional significance of D2 was demonstrated in vitro in $\mathrm{C} 2 \mathrm{C} 12$ cells and in a satellite cell-enriched primary culture of neonatal skeletal myocytes termed pp6 cells. In these in vitro models, the increase in D2 during differentiation increases conversion of $\mathrm{T} 4$ to $\mathrm{T} 3$ [40]. Increases in intracellular T4 to T3 conversion in D2-expressing tissues were confirmed in intact mice given injections of ${ }^{125}$ IT4 and ${ }^{131}$ IT3. In skeletal muscle,

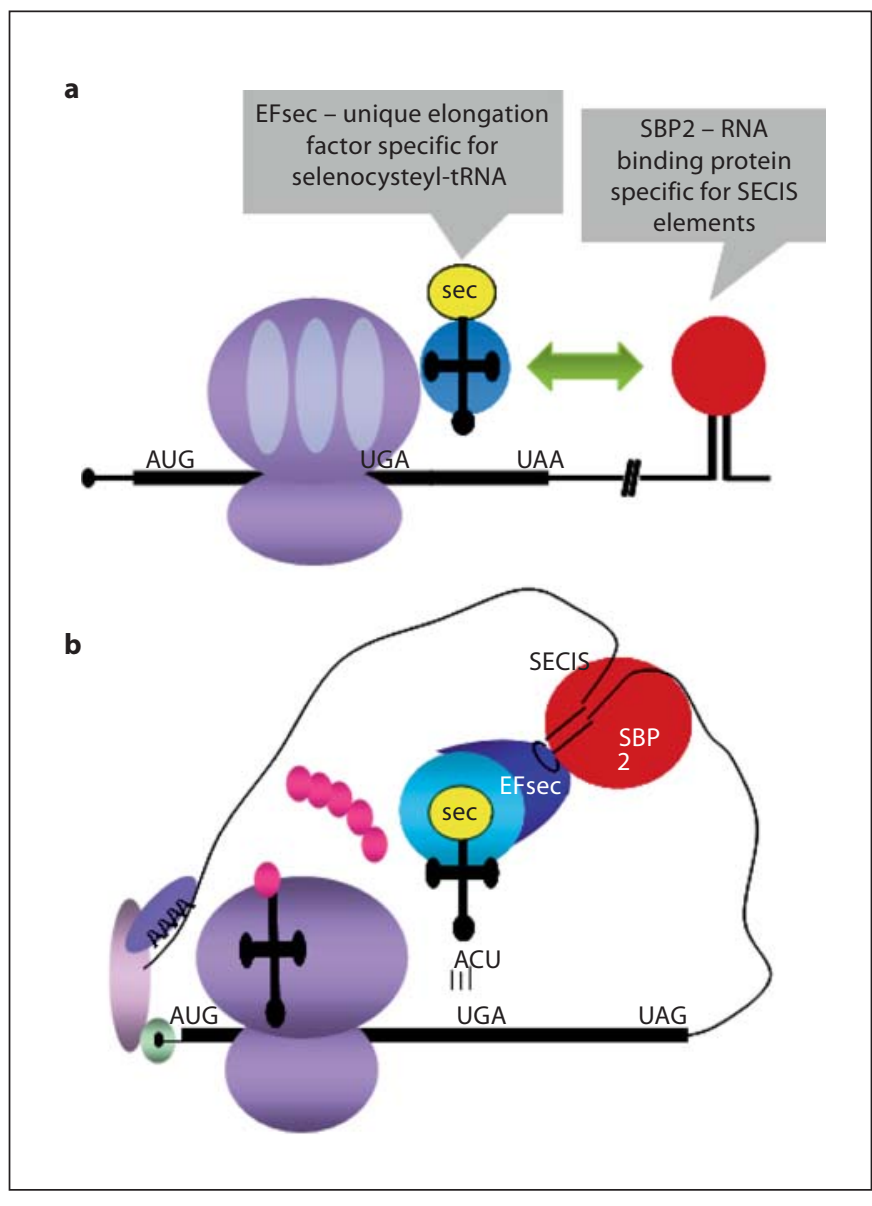

Fig. 2. Mechanism for selenoprotein synthesis. a Common structural features of selenoprotein mRNAs. $\mathbf{b}$ Mechanism for selenocysteine insertion. Kindly provided by Dr. Marla Berry, University of Hawaii at Manoa.

the ratio of $\mathrm{T} 3$ derived from $\mathrm{T} 4$ to that from serum was significantly higher in skeletal muscle than in serum, indicating the net production of ${ }^{125} \mathrm{IT} 3$ in those cells (fig. 4). This was also increased in skeletal muscle during the regeneration period after injury in parallel with increased D2 expression using the same techniques [40]. It does not occur in the D2KO mouse, confirming the physiological significance of D2 expression in skeletal muscle cells [41].

\section{Thyroid Hormone Inactivation by D3}

Type 3 deiodinase (D3) inactivates T3 and has significant actions during development and later in adult life. A major role for D3 is in the placenta, uterus, and the devel- 
Fig. 3. A tissue-specific increase in D2 at P6-8 in the cochlear tissue increases the T3 content of that tissue without perturbing the circulating concentration of T3. a From Campos-Barros et al. [37]. b, c With permission and adapted from CamposBarros et al. [37]. Copyright 2000 National Academy of Sciences, USA.

Fig. 4. Demonstration of the functional role of skeletal muscle D2 to provide intracellular ${ }^{125} \mathrm{IT} 3$ from circulating ${ }^{125} \mathrm{IT} 4$ analogous to the similar role of $\mathrm{D} 2$ in providing intracellular T3 to the central nervous system. The ${ }^{131}$ IT3 in all tissues is derived from circulating ${ }^{131}$ IT3. From Marsili et al. [40]. * $\mathrm{p}<0.05$ for difference from WT.
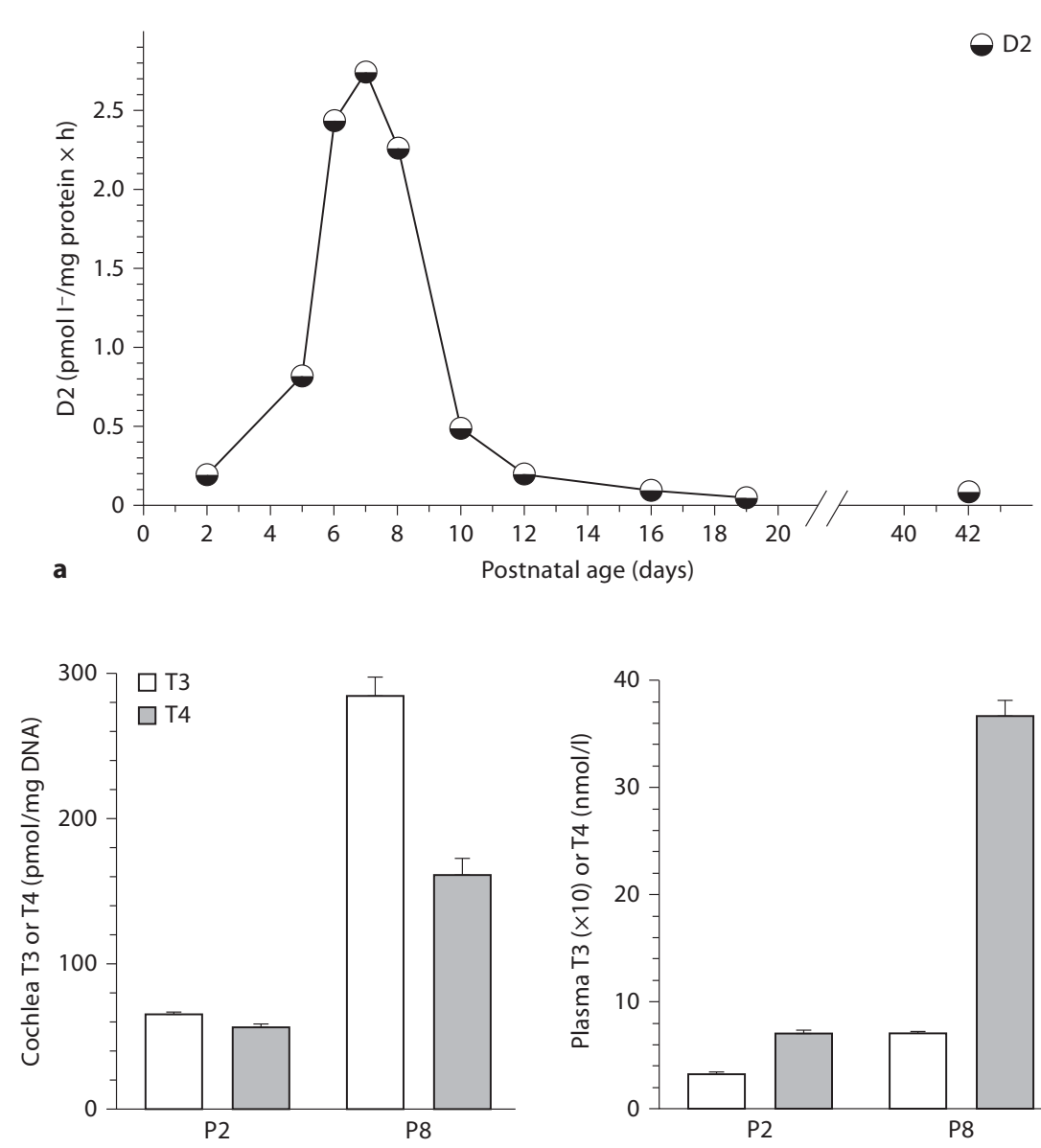

b

Age (days)

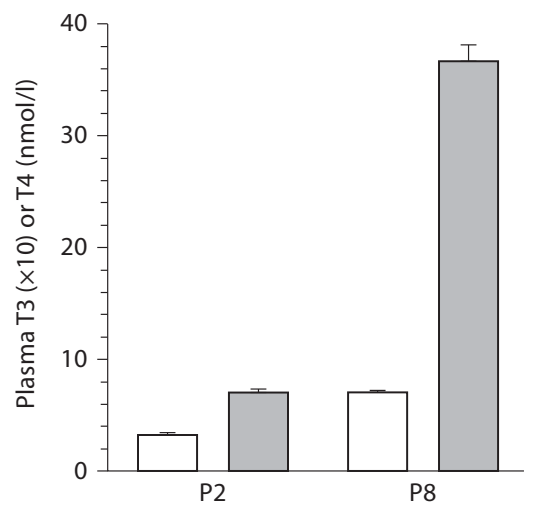

c

Age (days)

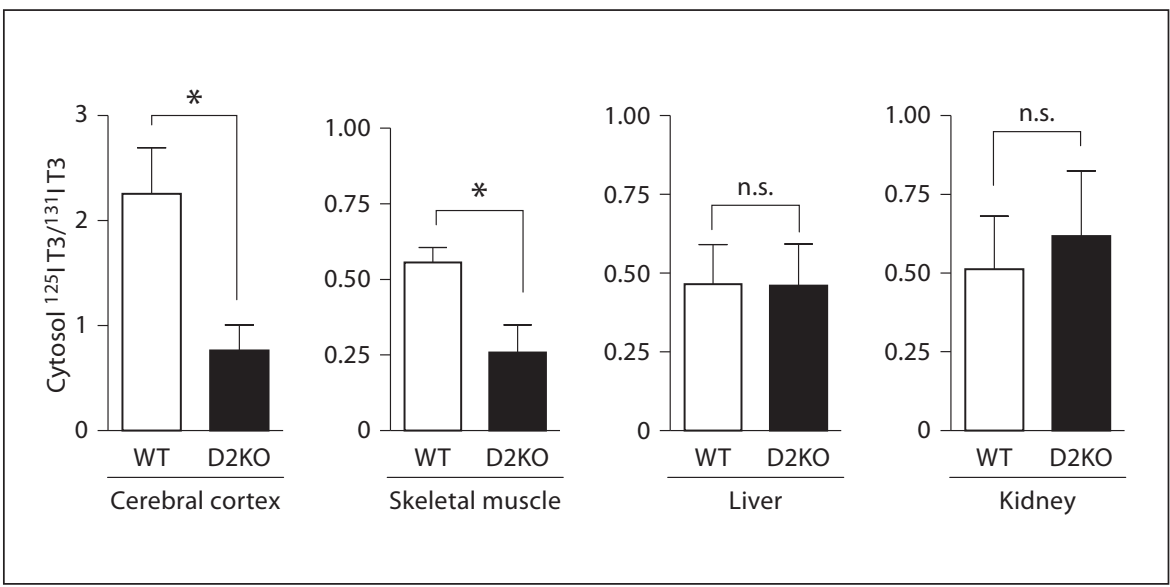


Fig. 5. Thyroid function and treatment during hospitalization in an infant with multiple hepatic hemangiomas. The shaded region is the normal range for serum thyrotropin concentrations (0.3-6.2 $\mu \mathrm{U} / \mathrm{mm})$, serum thyroxine concentrations $(6.8-13.3 \mu \mathrm{g} / \mathrm{dl}(88-171 \mathrm{nmol} / \mathrm{l}))$, serum triiodothyronine concentrations (86-170 $\mathrm{ng} / \mathrm{dl}(1.32-2.62 \mathrm{nmol} / \mathrm{l})$ ), and serum reverse triiodothyronine concentrations (10-50 ng/dl (0.15-0.77 nmol/l)). Each value is plotted relative to the normal range. Serum thyrotropin and reverse triiodothyronine concentrations are plotted on a logarithmic (base 10) scale. The infant was treated with intravenous (IV) infusions of both liothyronine and levothyroxine. The route of administration of levothyroxine was changed to nasojejunal on day 25 of hospitalization. From Huang et al. [47]. Copyright 2000 Massachusetts Medical Society.

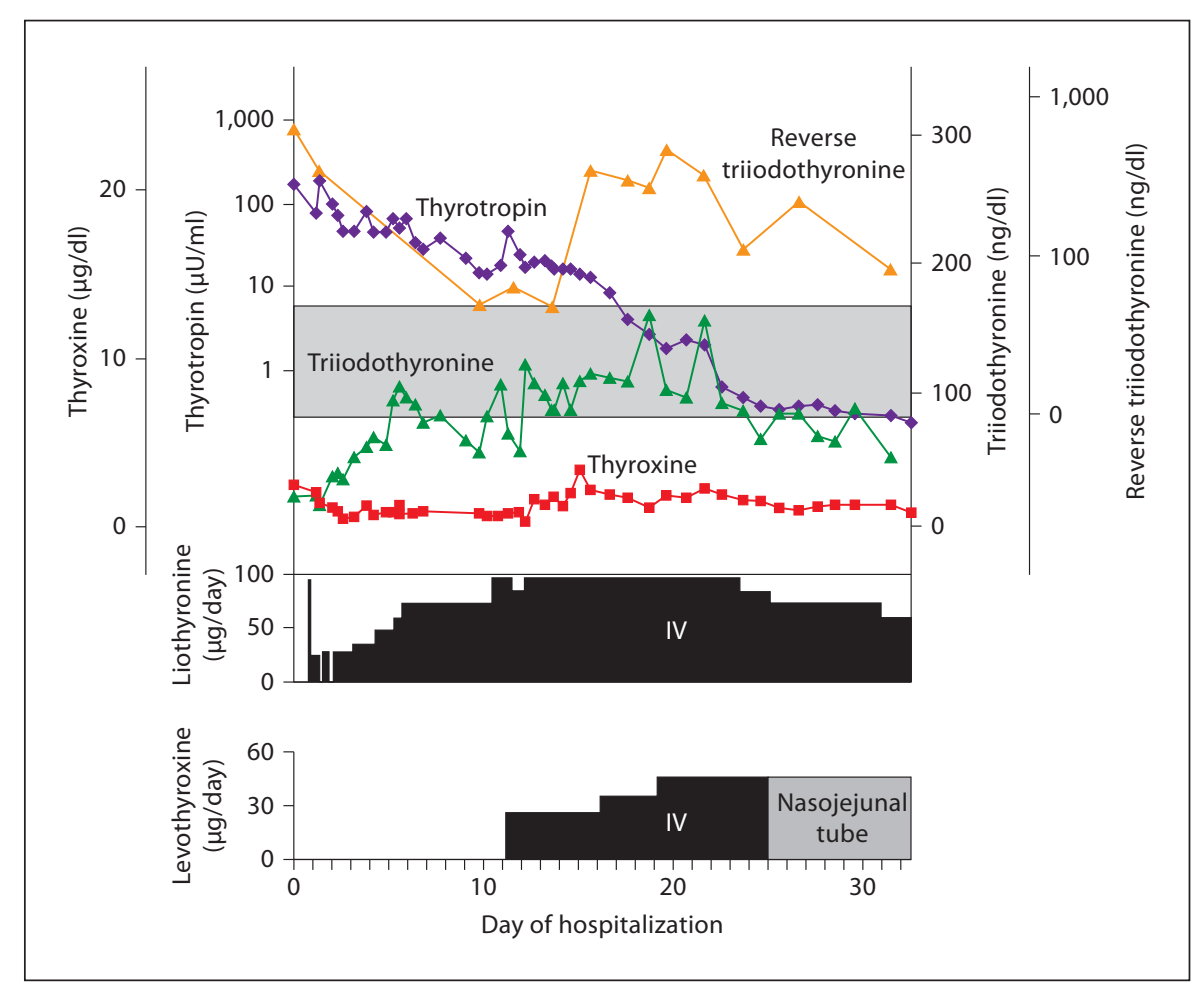

oping embryo/fetus protecting it from maternal T3 and T4. This allows the autonomous developmental program in the embryo and fetus to control the differentiation process. The increase in D3 during gestation may be enhanced by estradiol stimulation of the Dio3 promoter [42]. Particularly impressive is the presence of D3 in virtually every surface of the human fetus in contact with amniotic fluid, including the skin, alveolar cells, urothelium, and gastrointestinal tract [43]. The dramatic deleterious effects of D3 deficiency have been clearly demonstrated in the mouse D3 knockout model [44]. In these mice, the absence of D3 in the placenta and its marked reduction in the uterus allows free access of maternal thyroid hormone to the fetus and leads to impaired fertility and reprogramming of the HPT axis such that the postnatal D3 knockout mouse cannot maintain serum T4 concentrations at normal levels due to its insensitivity to the reduced concentrations of thyroid hormone. A similar but milder syndrome has been described in neonatal rats given exogenous thyroid hormone [45]. In the adult $\mathrm{D} 3 \mathrm{KO}$ mice, there is no response of TRH to hypothyroidism and the response of TSH to TRH is subnormal [46]. In addition, the thyroidal response to TSH is impaired and the thyroid markedly reduced in size in the D3KO mouse, suggesting that an intact HPT axis is required during development to establish the normal thyroidal responses to TSH [46].

Another striking example of the potency of D3 in humans is the syndrome of 'consumptive' hypothyroidism which can develop in human newborns with hepatic hemangiomas and even in adults with hepatic vascular tumors with high expression of D3 [1, 47, 48]. Hemangiomas are the most common tumors in infancy and are present in $5-10 \%$ of 1 -year-olds. They have a characteristic growth pattern, growing rapidly in the first year of life then decreasing in size and involuting during later years. In general, they are highly localized but rarely may spread beyond the original site and involve the liver. The first patient identified with this syndrome was an infant with neonatal hypothyroidism who had not had neonatal screening. He was initially thought to have primary congenital hypothyroidism due to the absence of thyroid tissue [47]. Levothyroxine therapy was initiated with an initial TSH response but the TSH later increased to above 200 which could not be attributed to poor compliance. The presence of a hepatic hemangioma was diagnosed by MRI and the suspected excessive D3 expression by the hemangioma was later confirmed in a postmortem tissue sample [47]. A serum thyroglobulin concentration was $>1,000 \mathrm{ng} / \mathrm{ml}$, indicating the presence of adequate thy- 


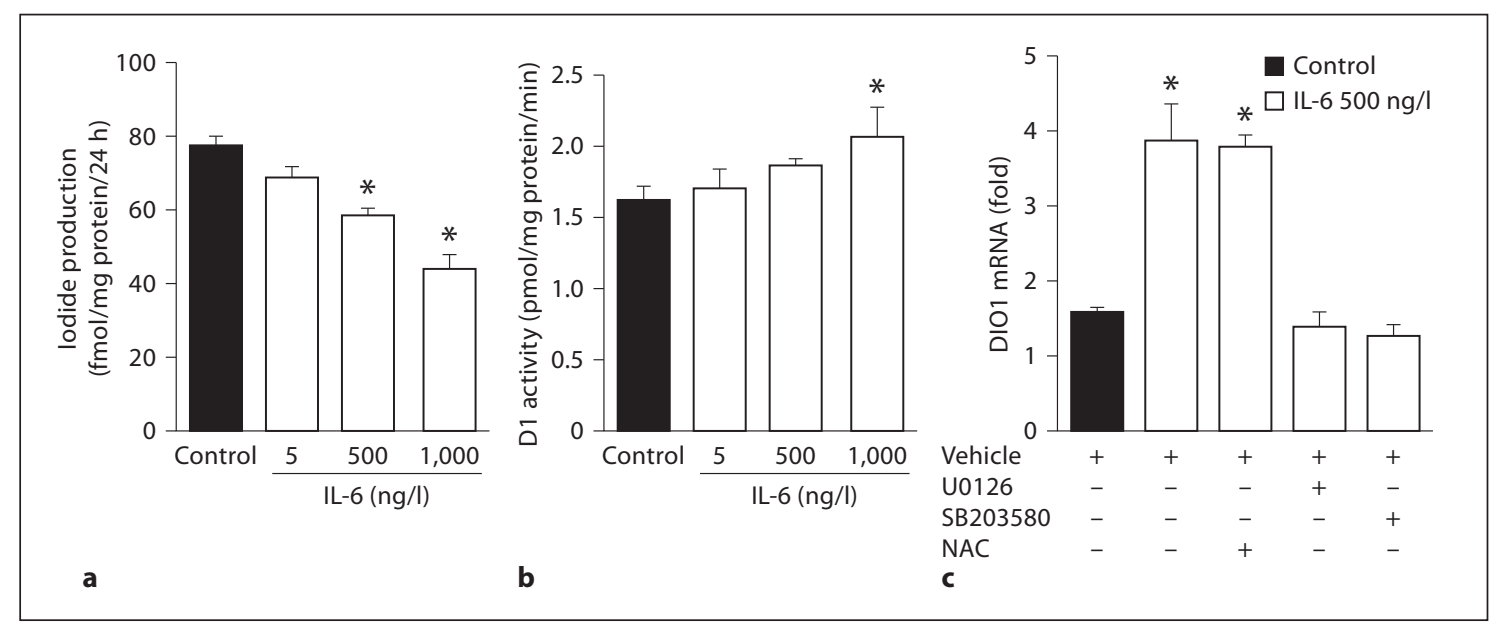

Fig. 6. Effects of IL- 6 on D1 activity and in mRNA in HepG2 cells: a exposure to IL- 6 for $24 \mathrm{~h}$ causes a dose-related decrease in outer ring deiodination by type 1 deiodinase despite an increase in total D1 activity in the same cells (b); c D1 mRNA was increased by
IL- 6 exposure and this was blocked by inhibition of the ERK pathway (UO126) or the MAPK pathway, which are induced by IL-6. $\mathrm{N}$-acetylcysteine (NAC) does not block this response. From Wajner et al. [23]. ${ }^{*} \mathrm{p}<0.05$ for difference from WT. roid tissue. The infant required nearly $100 \mu \mathrm{g}$ T3/day by infusion (about 3 -fold the daily $\mathrm{T} 3$ production in an adult) in addition to oral levothyroxine of $50 \mu \mathrm{g} /$ day, with subsequent normalization of serum $\mathrm{T} 3$ but no detectable serum T4. Serum rT3 was markedly elevated despite the absence of T4 (fig. 5) [47]. A similar adult patient was subsequently reported and a number of such patients have now been recognized [48]. Further studies showed that even localized hemangiomas express high levels of D3 [47], suggesting that this is part of the hemangiomatous process. D3 is also highly expressed in human and mouse basal-cell carcinoma, the most frequent human malignancy. These tumors are typically induced by uncontrolled Sonic hedgehog (Shh) activity and subsequent studies have demonstrated the presence of a conserved Gli2-binding site which induces D3 expression in proliferating keratinocytes and in mouse and human basal-cell carcinomas [49]. It is thought that T3 inactivation by $\mathrm{D} 3$ blocks cellular differentiation leading to continued proliferation of D3-expressing tumors. Knockdown of D3 or Shh in experimental basal-cell carcinomas results in a reduction in their proliferation rate and marked attenuation of growth in experimental tumors in nude mice [49].

Because of these syndromes and the expression of D3 in a number of different tumors, it has been referred to as an oncofetal protein. In experimental situations, the effect of D3 can be overcome either by suppression of its mRNA or by providing T3 to the cells in amounts in excess of that which can be inactivated by the $\mathrm{D} 3$ present.

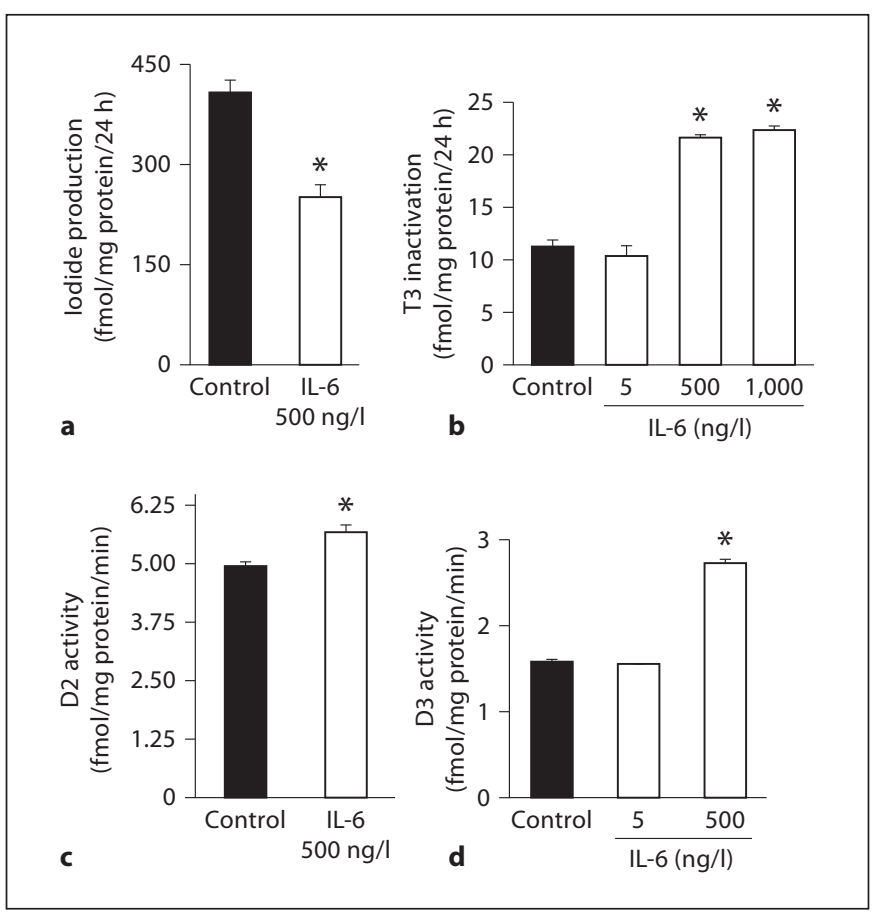

Fig. 7. Effects of IL- 6 on D2 or D3 activity in MSTO211 and MCF7 cells, respectively: a IL- 6 inhibits D2-mediated outer ring deiodination of T4 by intact MSTO211 cells despite an increase in total D2 activity in the same cells (c). In contrast, IL-6 increases T3 inactivation by intact MCF-7 cells (b) as expected from the increase in total D3 activity in the same cells (d). Both D2 and D3 mRNA were increased by IL- 6 through a MAPK-dependent process (data not shown). From Wajner et al. [23]. ${ }^{*} \mathrm{p}<0.05$ for difference from control. 
Fig. 8. Proposed mechanism for the effects of IL- 6 resulting in the low T3 or NTIS. From Wajner et al. [23].

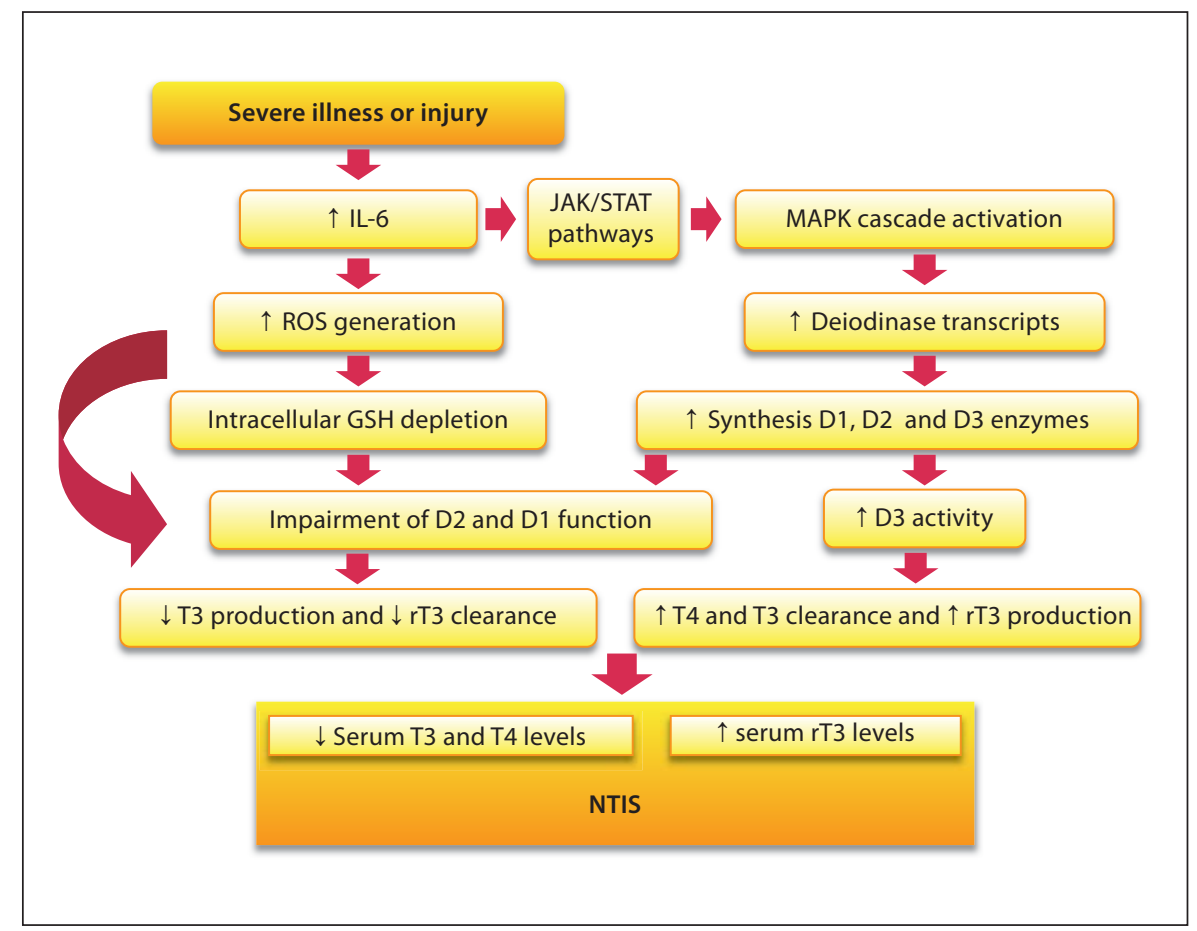

Recent studies have indicated that tyrosine kinase inhibitors, especially sunitinib, have an adverse effect on thyroid gland function possibly by reducing thyroid blood flow [50]. In addition, patients receiving sunitinib show increases in requirements for thyroid hormone over and above replacement doses and a decrease in the T3:rT3 ratio suggestive of increased D3 action [51]. These studies and the consumptive hypothyroidism reported in patients with hemangiomatous or other tumors of vascular origin illustrate the potency of this enzyme which causes inactivation of $\mathrm{T} 3$ and $\mathrm{T} 4$ at rates which exceed $\mathrm{T} 4$ and $\mathrm{T} 3$ production capacities even with a high TSH [47].

A less severe form of consumptive hypothyroidism probably accounts for the increased levothyroxine requirements during pregnancy and with oral contraceptives, since the Dio3 gene is transcriptionally stimulated by estradiol [42]. D3 activity has been identified in a number of malignancies, including gliomas, neuroblastomas, and colon carcinomas, all of which are derived from cells which are known or thought to be capable of $\mathrm{D} 3$ production in the embryo. In many of these an increase in Shh signaling is involved, while recent studies have shown that $\beta$-catenin is responsible for the D3 increases in adenomas and carcinomas of colonic epithelium [52].

Recent evidence also supports an element of consumptive hypothyroidism as a contributing cause of the 'low T3 syndrome' during human illness. Non-thyroidal illness syndrome (NTIS) is characterized by low T3 and elevated rT3, and is correlated with a lower hepatic D1, while D3 is markedly increased in both liver and skeletal muscle of critically ill patients $[53,54]$. Insight into a potential mechanism for these disparate changes can be found in studies where the effects of the cytokine IL- 6 on iodothyronine deiodination by intact human cells were found to differ between those expressing D1 or D2 (HepG2 and MSTO211 cells, respectively), and the human $\mathrm{D} 3$-expressing breast cancer cell line, MCF-7. IL-6 concentrations typical of those in the serum of sick patients caused an increase in reactive oxygen species (ROS) in all three cell lines which induced the transcription of deiodinase mRNA and protein in each of the cells through the MAPK/ERK pathways [23]. A striking result was that the increase in D1 and D2 activity in the cell lysates was not accompanied by increases in the $5^{\prime}$ deiodination of T4 by intact HepG2 and MSTO211 cells but the increase in cellular D3 was accurately reflected by an increase in $\mathrm{T} 3$ inactivation by intact MCF-7 cells (fig 6, 7) [23]. A similar result was obtained by inducing $\mathrm{ROS}$ by exposure to $\mathrm{H}_{2} \mathrm{O}_{2}$. A plausible explanation for these differences is that there is a greater sensitivity of D3 to the extracellular space as a source of thiol cofactor compared to that of D1 and D2 which depend predominantly on cytosolic thiols (fig. 8) [23]. In any case, 
this is the first demonstration of the effect of a single event, an increase in cellular ROS, to suppress outer ring deiodinase activity while increasing that of D3-mediated inner ring deiodination, replicating the classical pattern of the reduced T3 and elevated rT3 in NTIS.

These clinically relevant aspects of deiodinase physiology illustrate the important role of these enzymes in the activation or inactivation of thyroid hormones. The local production of thyroid hormone is a highly regulated process during embryonic and fetal life, as well as during regeneration. A number of tissues, including skeletal muscle, skin, intestine, and the central nervous system, have been shown to co-express D2 and D3, and many studies are currently underway to define how the activation and inactivation by these deiodinases is regulated by factors such as hedgehog proteins, FoxO3, and wnt $/ \beta$ catenin to modulate the intracellular concentration of T3 in specific cells without perturbing that of $\mathrm{T} 4$ or $\mathrm{T} 3$ in the circulation.

\section{Acknowledgements}

The authors regret that the space limitations for this invited review preclude a thorough list of citations relevant to this topic. This work was supported by research grants from the National Institutes of Health.

\section{Disclosure Statement}

The authors have no conflicts of interest to disclose.

\section{References}

1 Bianco AC, Salvatore D, Gereben B, Berry MJ, Larsen PR: Biochemistry, cellular and molecular biology, and physiological roles of the iodothyronine selenodeiodinases. Endocr Rev 2002;23:38-89.

2 Larsen PR, Frumess RD: Comparison of the biological effects of thyroxine and triiodothyronine in the rat. Endocrinology 1977; 100:980-988.

-3 Cheron RG, Kaplan MM, Larsen PR: Physiological and pharmacological influences on thyroxine to 3,5,3'-triiodothyronine conversion and nuclear 3,5,3'-triiodothyronine binding in rat anterior pituitary. J Clin Invest 1979;64:1402-1414

4 Riskind PN, Kolodny JM, Larsen PR: The regional hypothalamic distribution of type II $5^{\prime}$-monodeiodinase in euthyroid and hypothyroid rats. Brain Res 1987;420:194-198.

-5 Christoffolete MA, Ribeiro R, Singru P, Fekete C, da Silva WS, Gordon DF, Huang SA, Crescenzi A, Harney JW, Ridgway EC, Larsen PR, Lechan RM, Bianco AC: Atypical expression of type 2 iodothyronine deiodinase in thyrotrophs explains the thyroxinemediated pituitary thyrotropin feedback mechanism. Endocrinology 2006;147:17351743.

6 Heuer H, Visser TJ: Pathophysiological importance of thyroid hormone transporters. Endocrinology 2009;150:1078-1083.

7 Visser WE, Friesema EC, Visser TJ: Minireview: Thyroid hormone transporters: the knowns and the unknowns. Mol Endocrinol 2010;25:1-14

8 Schweizer U, Kohrle J: Function of thyroid hormone transporters in the central nervous system. Biochim Biophys Acta 2012, E-pub ahead of print.

\section{-9 Fliers E, Alkemade A, Wiersinga WM, Swaab} DF: Hypothalamic thyroid hormone feedback in health and disease. Prog Brain Res 2006;153:189-207.

10 Oppenheimer JH, Schwartz HL: Stereospecific transport of triiodothyronine from plasma to cytosol and from cytosol to nucleus in rat liver, kidney, brain, and heart. J Clin Invest 1985;75:147-154.

11 Silva JE, Larsen PR: Potential of brown adipose tissue type II thyroxine $5^{\prime}$-deiodinase as a local and systemic source of triiodothyronine in rats. JClin Invest 1985;76:2296-2305.

12 Dentice M, Marsili A, Zavacki A, Larsen PR, Salvatore D: The deiodinases and the control of intracellular thyroid hormone signaling during cellular differentiation. Biochim Biophys Acta 2012, E-pub ahead of print.

13 Tu HM, Legradi G, Bartha T, Salvatore D, Lechan RM, Larsen PR: Regional expression of the type 3 iodothyronine deiodinase messenger ribonucleic acid in the rat central nervous system and its regulation by thyroid hormone. Endocrinology 1999;140:784-790.

14 Barrett P, Ebling FJ, Schuhler S, Wilson D, Ross AW, Warner A, Jethwa P, Boelen A, Visser TJ, Ozanne DM, Archer ZA, Mercer JG, Morgan PJ: Hypothalamic thyroid hormone catabolism acts as a gatekeeper for the seasonal control of body weight and reproduction. Endocrinology 2007; 148:36083617.

15 Tu HM, Kim SW, Salvatore D, Bartha T, Legradi G, Larsen PR, Lechan RM: Regional distribution of type 2 thyroxine deiodinase messenger ribonucleic acid in rat hypothalamus and pituitary and its regulation by thyroid hormone. Endocrinology 1997; 138: 3359-3368.
16 Peeters R, Fekete C, Goncalves C, Legradi G Tu HM, Harney JW, Bianco AC, Lechan RM, Larsen PR: Regional physiological adaptation of the central nervous system deiodinases to iodine deficiency. Am J Physiol Endocrinol Metab 2001;281:E54-E61.

17 Pitt-Rivers R, Stanbury JB, Rapp B: Conversion of thyroxine to 3,5,3'-triiodothyronine in vivo. J Clin Endocrinol Metab 1955; 15: 616-620.

18 Izumi M, Larsen PR: Triiodothyronine, thyroxine, and iodine in purified thyroglobulin from patients with Graves' disease. J Clin Invest 1977;59:1105-1112.

19 Salvatore D, Tu H, Harney JW, Larsen PR: Type 2 iodothyronine deiodinase is highly expressed in human thyroid. J Clin Invest 1996;98:962-968.

20 Riesco G, Taurog A, Larsen R, Krulich L: Acute and chronic responses to iodine deficiency in rats. Endocrinology 1977; 100:303313.

21 Galton VA, Schneider MJ, Clark AS, St Germain DL: Life without thyroxine to 3,5,3'triiodothyronine conversion: studies in mice devoid of the $5^{\prime}$-deiodinases. Endocrinology 2009;150:2957-2963.

-22 Gereben B, Zavacki AM, Ribich S, Kim BW, Huang SA, Simonides WS, Zeold A, Bianco AC: Cellular and molecular basis of deiodinase-regulated thyroid hormone signaling. Endocr Rev 2008;29:898-938.

23 Wajner SM, Goemann IM, Bueno AL, Larsen PR, Maia AL: IL- 6 promotes nonthyroidal illness syndrome by blocking thyroxine activation while promoting thyroid hormone inactivation in human cells. J Clin Invest 2011; 121:1834-1845. 
24 Berry MJ, Banu L, Larsen PR: Type 1 iodothyronine deiodinase is a selenocysteine-containing enzyme. Nature 1991;349:438-440.

-25 Berry MJ, Kieffer JD, Harney JW, Larsen PR: Selenocysteine confers the biochemical properties characteristic of the type 1 iodothyronine deiodinase. J Biol Chem 1991;266: 14155-14158.

-26 Berry MJ, Banu L, Chen YY, Mandel SJ, Kieffer JD, Harney JW, Larsen PR: Recognition of UGA as a selenocysteine codon in type I deiodinase requires sequences in the $3^{\prime}$ untranslated region. Nature 1991;353:273-276.

27 Berry MJ: Knowing when not to stop. Nat Struct Mol Biol 2005;12:389-390.

28 Larsen PR, Silva JE, Kaplan MM: Relationships between circulating and intracellular thyroid hormones: physiological and clinical implications. Endocr Rev 1981;2:87-102.

-29 Silva JE, Larsen PR: Pituitary nuclear 3,5,3'triiodothyronine and thyrotropin secretion: an explanation for the effect of thyroxine. Science 1977;198:617-620.

-30 Oppenheimer JH, Schwartz HL, Surks MI: Propylthiouracil inhibits the conversion of L-thyroxine to L-triiodothyronine. An explanation of the antithyroxine effect of propylthiouracil and evidence supporting the concept that triiodothyronine is the active thyroid hormone. J Clin Invest 1972;51: 2493-2497.

- 31 Visser TJ, Kaplan MM, Leonard JL, Larsen PR: Evidence for two pathways of iodothyronine $5^{\prime}$-deiodination in rat pituitary that differ in kinetics, propylthiouracil sensitivity, and response to hypothyroidism. J Clin Invest 1983;71:992-1002.

- 32 Abuid J, Larsen PR: Triiodothyronine and thyroxine in thyrotoxicosis: acute response to therapy and anti-thyroid agents. J Clin Endocrinol Metab 1974;38:263-268.

- 33 Laurberg P, Vestergaard H, Nielsen S, Christensen SE, Seefeldt T, Helleberg K, Pedersen KM: Sources of circulating 3,5,3'-triiodothyronine in hyperthyroidism estimated after blocking of type 1 and type 2 iodothyronine deiodinases. J Clin Endocrinol Metab 2007;92:2149-2156.

34 Maia AL, Kim BW, Huang SA, Harney JW, Larsen PR: Type 2 iodothyronine deiodinase is the major source of plasma T3 in euthyroid humans. J Clin Invest 2005;115:2524-2533.

-35 Steinsapir J, Harney J, Larsen PR: Type 2 iodothyronine deiodinase in rat pituitary tumor cells is inactivated in proteasomes. J Clin Invest 1998;102:1895-1899.
36 Steinsapir J, Bianco AC, Buettner C, Harney J, Larsen PR: Substrate-induced down-regulation of human type 2 deiodinase (hD2) is mediated through proteasomal degradation and requires interaction with the enzyme's active center. Endocrinology 2000;141:11271135.

37 Campos-Barros A, Amma LL, Faris JS, Shailam R, Kelley MW, Forrest D: Type 2 iodothyronine deiodinase expression in the cochlea before the onset of hearing. Proc Natl Acad Sci USA 2000;97:1287-1292.

38 Ng L, Goodyear RJ, Woods CA, Schneider MJ, Diamond E, Richardson GP, Kelley MW, Germain DL, Galton VA, Forrest D: Hearing loss and retarded cochlear development in mice lacking type 2 iodothyronine deiodinase. Proc Natl Acad Sci USA 2004;101:34743479.

39 Dentice M, Marsili A, Ambrosio R, Guardiola O, Sibilio A, Paik JH, Minchiotti G, DePinho RA, Fenzi G, Larsen PR, Salvatore D: The FoxO3/type 2 deiodinase pathway is required for normal mouse myogenesis and muscle regeneration. J Clin Invest 2010;120: 4021-4030.

40 Marsili A, Tang D, Harney JW, Singh P, Zavacki AM, Dentice M, Salvatore D, Larsen PR: Type 2 iodothyronine deiodinase provides intracellular 3,5,3'-triiodothyronine to normal and regenerating mouse skeletal muscle. Am J Physiol Endocrinol Metab 2011;301:E818-E824.

-41 Marsili A, Ramadan W, Harney JW, Mulcahey $\mathrm{M}$, Castroneves LA, Goemann IM, Wajner SM, Huang SA, Zavacki AM, Maia AL, Dentice M, Salvatore D, Silva JE, Larsen PR: Type 2 iodothyronine deiodinase levels are higher in slow-twitch than fast-twitch mouse skeletal muscle and are increased in hypothyroidism. Endocrinology 2010;151: 5952-5960.

42 Huang SA, Mulcahey MA, Crescenzi A, Chung M, Kim BW, Barnes C, Kuijt W, Turano H, Harney J, Larsen PR: Transforming growth factor- $\beta$ promotes inactivation of extracellular thyroid hormones via transcriptional stimulation of type 3 iodothyronine deiodinase. Mol Endocrinol 2005;19:31263136.

43 Huang SA, Dorfman DM, Genest DR, Salvatore D, Larsen PR: Type 3 iodothyronine deiodinase is highly expressed in the human uteroplacental unit and in fetal epithelium. J Clin Endocrinol Metab 2003;88:1384-1388.

$\checkmark 44$ Hernandez A, Martinez ME, Fiering S, Galton VA, St Germain D: Type 3 deiodinase is critical for the maturation and function of the thyroid axis. J Clin Invest 2006;116:476484.

45 Bakke JL, Lawrence N, Wilber JF: The late effects of neonatal hyperthyroidism upon the hypothalamic-pituitary-thyroid axis in the rat. Endocrinology 1974;95:406-411.
46 Hernandez A, Martinez ME, Liao XH, Van Sande J, Refetoff S, Galton VA, St Germain DL: Type 3 deiodinase deficiency results in functional abnormalities at multiple levels of the thyroid axis. Endocrinology 2007; 148: 5680-5687.

47 Huang SA, Tu HM, Harney JW, Venihaki M, Butte AJ, Kozakewich HP, Fishman SJ, Larsen PR: Severe hypothyroidism caused by type 3 iodothyronine deiodinase in infantile hemangiomas. N Engl J Med 2000;343:185189.

48 Huang SA, Fish SA, Dorfman DM, Salvatore D, Kozakewich HP, Mandel SJ, Larsen PR: A 21-year-old woman with consumptive hypothyroidism due to a vascular tumor expressing type 3 iodothyronine deiodinase. J Clin Endocrinol Metab 2002;87:4457-4461.

-49 Dentice M, Luongo C, Huang S, Ambrosio R, Elefante A, Mirebeau-Prunier D, Zavacki AM, Fenzi G, Grachtchouk M, Hutchin M, Dlugosz AA, Bianco AC, Missero C, Larsen PR, Salvatore D: Sonic hedgehog-induced type 3 deiodinase blocks thyroid hormone action enhancing proliferation of normal and malignant keratinocytes. Proc Natl Acad Sci USA 2007;104:14466-14471.

50 Desai J, Yassa L, Marqusee E, George S, Frates MC, Chen MH, Morgan JA, Dychter SS, Larsen PR, Demetri GD, Alexander EK: Hypothyroidism after sunitinib treatment for patients with gastrointestinal stromal tumors. Ann Intern Med 2006;145:660-664.

51 Kappers MH, van Esch JH, Smedts FM, de Krijger RR, Eechoute K, Mathijssen RH, Sleijfer S, Leijten F, Danser AH, van den Meiracker AH, Visser TJ: Sunitinib-induced hypothyroidism is due to induction of type 3 deiodinase activity and thyroidal capillary regression. J Clin Endocrinol Metab 2011;96: 3087-3094.

52 Dentice M, Luongo C, Ambrosio R, Sibilio A, Casillo A, Iaccarino A, Troncone G, Fenzi G, Larsen PR, Salvatore D: Beta-catenin regulates deiodinase levels and thyroid hormone signaling in colon cancer cells. Gastroenterology 2012;143:1037-1047.

53 Peeters RP, van der Geyten S, Wouters PJ, Darras VM, van Toor H, Kaptein E, Visser TJ, Van den Berghe G: Tissue thyroid hormone levels in critical illness. J Clin Endocrinol Metab 2005;90:6498-6507.

54 Peeters RP, Wouters PJ, van Toor H, Kaptein E, Visser TJ, Van den Berghe G: Serum 3,3',5'-triiodothyronine (rT3) and 3,5,3'triiodothyronine/rt3 are prognostic markers in critically ill patients and are associated with postmortem tissue deiodinase activities. J Clin Endocrinol Metab 2005;90:45594565. 